\section{Comment}

During treatment with inhaled beclomethasone the osteocalcin concentrations decreased, as has been observed in patients taking oral corticosteroids. This might imply that during beclomethasone treatment bone formation is depressed, which could result in osteoporosis in the long run.

In our pilot study we investigated healthy subjects who used a high dose of beclomethasone for a short period of time. Whether osteocalcin concentrations are also lowered in asthmatic patients treated with lower doses of beclomethasone over the long term is unknown at present. This is not unlikely, however-firstly, because the resorption of the drug might be better in patients than in healthy subjects and, secondly, because osteocalcin remained depressed during long term treatment of patients with oral corticosteroids. ${ }^{+}$There- fore a longitudinal study measuring serum osteocalcin concentrations and bone mineral density in newly diagnosed patients with asthma taking inhaled corticosteroids seems warranted.

We thank Mrs W Norder-Paulides for technical assistance.

1 Barnes PJ. A new approach to the treatment of asthma. $N$ Engl $f$ Med 1989;321:571-25

2 Capewell S, Reynolds S, Shuttleworth D, Edwards C, Finlay AY. Purpura and dermal thinning associated with high dose inhaled corticosteroids. $B M$ 1990;300:1548-51.

3 Brown JP, Delmas PD, Malaval L, Edouard C, Chapuy MC, Meunier P]. Serum bone Gla-protein: a specific marker for bone formation in postmenopausal osteoporosis. Lancet 1984;i:1091-3.

4 Prummel MF, Wiersinga WM, Lips P, Sanders GTB, Sauerwein HP. The course of biochemical parameters of bone turnover during treatment with corticosteroids. F Clin Endocrinol Metab 1991;72:382-6.

5 Gundberg CM, Markowitz ME, Mizruchi M, Rosen JF. Osteocalcin in human serum: a circadian rhythm. F Clin Endocrinol Metab 1985;60:736-9.

(Accepted 12 January 1991)
Harris Birthright Research Centre for Fetal Medicine, Department of Obstetrics and Gynaecology, King's College School of Medicine and Dentistry, London SE5 8RX

J G Thorpe-Beeston, MRCOG, research registrar K H Nicolaides, MRCOG, consultant

M R C Human Genetics Unit, Western General Hospital, Edinburgh

C M Gosden, PHD, professor

Department of Medicine, King's College School of Medicine and Dentistry

A M McGregor, MD, professor

Correspondence to: $\mathrm{Mr}$ Nicolaides.

BMF 1991;302:628

\title{
Thyroid function in fetuses with chromosomal abnormalities
}

\section{J G Thorpe-Beeston, K H Nicolaides, C $M$ Gosden, A M McGregor}

In children with Down's syndrome the incidence of thyroid disorders is reported to be $6 \%$, which is 28 times higher than that expected in the general population. ${ }^{1}$ Evidence suggests that early diagnosis and effective treatment may not only improve the physical wellbeing of such infants but also have an appreciable impact on intellectual function. ${ }^{2}$ We aimed at determining whether there is in utero evidence of thyroid dysfunction in fetuses with chromosomal abnormalities.

\section{Methods and results}

Using radioimmunoassay, we measured serum thyroid stimulating hormone, free and total thyroxine, and triiodothyronine concentrations in umbilical venous blood samples obtained by cordocentesis from 15 fetuses with chromosomal abnormalities (trisomy 21 (five), trisomy 18 (five), trisomy 13 (one), triploidy (two), and Klinefelter's syndrome (two)) at 17-36 weeks' gestation. ${ }^{34}$ The indication for cordocentesis was fetal karyotyping after fetal malformations had been detected by ultrasonography. Informed consent was obtained from the mothers, and the project was approved by the hospital ethical committee.

In the five fetuses with Down's syndrome, two of the five with trisomy 18 , and one of the two with triploidy thyroid stimulating hormone concentration was above the 95 th centile of the reference range (figure). In all 15 fetuses, however, thyroid hormone concentrations were within the reference ranges, and the mean values were not significantly different from the normal means for gestation (free triiodothyronine concentration: mean difference $=0 \cdot 118 \mathrm{SD}, t=0 \cdot 30$; free thyroxine: $-0.249 \mathrm{SD}, t=0.61$; total triiodothyronine: $0.705 \mathrm{SD}$, $t=2 \cdot 87$; total thyroxine: $0 \cdot 225 \mathrm{SD} t=0 \cdot 56$ ).

\section{Comment}

The high thyroid stimulating hormone in some fetuses with a chromosomal abnormality, particularly those with trisomy 21 , may be an early manifestation of relative hypothyroidism. Animal studies have

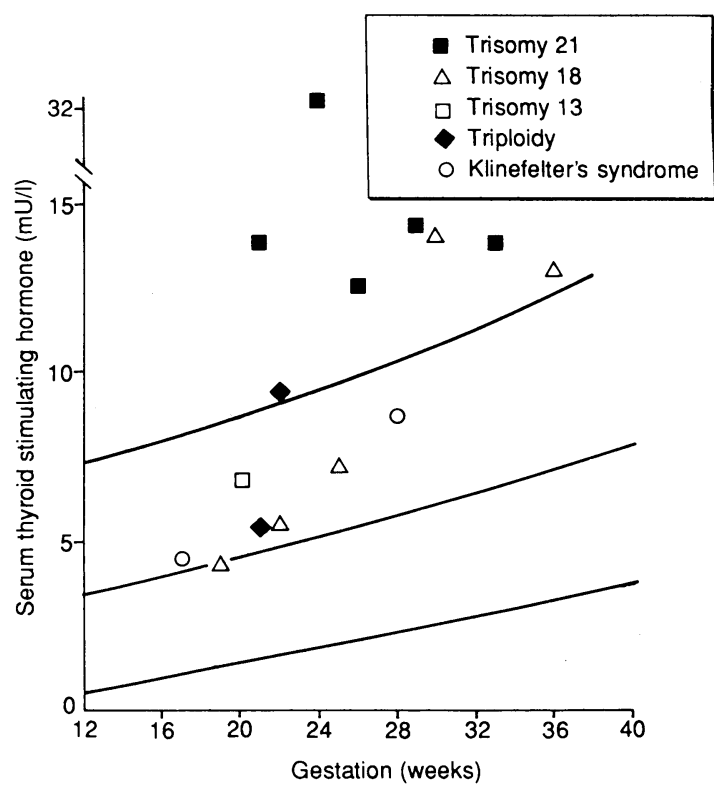

Serum thyroid stimulating hormone concentration in 15 fetuses with chromosomal abnormalities plotted on reference range (mean values and 5 th and 95 th centiles $)^{4}$ for gestation

suggested that thyroid hormones have a critical role in the growth and functional development of the brain. In humans congenital hypothyroidism is associated with appreciable abnormalities in physical and neurological development, manifested at its extreme by cretinism. Prompt postnatal treatment usually prevents these adverse sequelae. Intrauterine hypothyroidism of early onset, as documented in some fetuses with chromosomal abnormalities, could, however, result in irreversible brain damage and may be one of the underlying causes of mental handicap in such infants. The extent to which intrauterine hormone supplementation would reduce impaired neurological development remains to be determined.

1 Cutler AT, Benezra-Obeiter R, Brink SJ. Thyroid function in young children with Down syndrome. Am $\mathcal{F}$ Dis Child 1986;140:479-83.

2 Pueschel SM, Pessullo JC. Thyroid dysfunction in Down syndrome. Am $\mathcal{J}$ Dis Child 1985;139:636-9.

3 Nicolaides KH, Soothill PW, Rodeck CH, Campbell S. Ultrasound-guided sampling of the umbilical cord and placental blood to assess fetal well-being. Lancet 1986; ;: 1065-7.

4 Thorpe-Beeston JG, Nicolaides KH, Felton CV, Butler J, McGregor AM. Maturation of the fetal thyroid and increasing secretion of thyroid stimulating hormone. N Engl f Med 1991;324:532-6.

5 de Escabor GM, Obregon MJ, del Rey FE. Fetal and maternal thyroid hormones. Horm Res 1987;26:12-27.

(Accepled 8 fanuary 1991) 